\title{
Oral Mucosa
}

National Cancer Institute

\section{Source}

National Cancer Institute. Oral Mucosa. NCI Thesaurus. Code C77637.

Moist tissue lining the oral cavity, containing mucous secreting glands. 